\title{
Lawyers in transition - Palestinian Arab lawyers in the first decade of the Jewish state
}

\author{
Gal $\mathrm{Amir}^{1 *}$ and Na'ama Ben $\mathrm{Ze}^{\prime} \mathrm{ev}^{2}$ \\ ${ }^{1}$ Faculty of Law and the Jewish-Arab Center, University of Haifa and ${ }^{2}$ Israel Studies Department, University \\ of Haifa \\ ${ }^{*}$ Corresponding author. Email: agal39@yahoo.com
}

\begin{abstract}
This article traces the careers of 12 Palestinian Arab lawyers who practised law during the last years of the British Mandate in Palestine (1920-1948), and who became Israeli citizens after 1948. The State of Israel made efforts to limit the professional practice of Palestinian lawyers and to supervise them. Yet, despite the pressures, most of them continued their legal practice and became active in the Israeli public sphere. We show that the Palestinian lawyers' struggle to maintain their practice in Israel was used to assert autonomy for the legal profession, and concurrently, it was perceived as a touchstone for minority civil rights in the state.
\end{abstract}

In 1947, 110 Palestinian Arab ${ }^{1}$ lawyers, whose office addresses were in the territories that would soon become the State of Israel, were listed in the British Mandate government's 'Roll of Advocates'. A subsequent list, published in 1952, four years after the State of Israel was founded, included only nine of them. These numbers reflect the demographic change that occurred in Palestine during the transition from the British Mandate to the independent State of Israel. ${ }^{2}$ By any measure, this was a calamity. Prosperous legal centres that operated in cities like Jaffa, Haifa and Acre were completely wiped out or reduced to a fraction of their original size. The damage to the legal profession was only one aspect of the blow to the Palestinian Arab population as a whole. It was part of the decimation of most Palestinian Arab urban communities. Of the large, once prosperous, influential urban community of Palestinian Arab lawyers, only a small, heterogeneous and weakened group remained.

Members of this group had to deal with the trauma of the 1948 war (in which some had been involved in command and leadership positions) and adjust to their new status as a minority subject to discrimination in the Jewish state. They belonged to a thin layer of educated middle-class urbanites who remained under the rule of the State of Israel after the Nakba. ${ }^{3}$ This population suffered from the loss of both material assets and a significant part of their pre-war peer group, as entire urban communities ceased to exist and others declined considerably. ${ }^{4}$ 
This article traces the careers of 12 Palestinian Arab lawyers who practised law during the last years of the British Mandate in Palestine (1920-1948), and who became Israeli citizens after 1948. Although the article reviews their training and licencing routes in the pre-state era, it concentrates on the difficulties posed by the transition from British Mandate rule to that of the Jewish state. Most of these lawyers continued their legal practice and became active in the Israeli public sphere at a time when Palestinian involvement in Israeli politics was overseen and controlled by state authorities. We show that the Palestinian lawyers' struggle to maintain their practice in Israel was used to assert autonomy for the legal profession, and concurrently, it was perceived as a touchstone for minority civil rights in the state. Our analysis focuses on efforts made by the State of Israel to limit the professional practice of Palestinian lawyers and to supervise them. The interaction between state officials and these lawyers became a professional conflict. We argue that Israeli security officials expected Jewish lawyers' representatives in state institutions and in the bar association to comply with their restrictive policy against Palestinian lawyers. To mobilise leading Jewish lawyers' cooperation, they used security argumentation and tried to evoke national and collectivist sentiment. Yet the Jewish lawyers' leadership staunchly opposed this étatisme, revealing concern for the rule of law and for professional interests that transcended national divisions.

Despite the prominent role that Palestinian Arab lawyers played in the public sphere during the Mandate and the Israeli rule that followed, they have gained only limited scholarly attention. Assaf Likhovski claims that the Palestinian Arab legal community in Mandatory Palestine was less developed than both the Jewish one and its counterparts in Arab countries, in terms of the number of legal publications and the establishment of institutions such as law schools or professional associations. ${ }^{5}$ Donald M. Reid, who examined the involvement of lawyers in political activity in several Arab states, discusses training and licencing of lawyers under the British administration but does not address the time after $1948 .^{6} \mathrm{~A}$ few works review the Jewish Bar Association, which was established in 1928 and continued operating after 1948 until the formation of the statutory bar association in 1961. However, the Arab Bar Association, also established during the Mandate, ceased to exist following the Nakba and was only briefly mentioned in those works. ${ }^{7}$

Primary sources on the Palestinian Arab lawyers during the time under discussion include official documents such as correspondence and reports maintained at the Israel State Archives, published court rulings, and unpublished court documents. Some cases involving Palestinian Arab lawyers were discussed in Israeli papers, in Hebrew and Arabic. A few of the lawyers engaged in writing commentary for Arab newspapers and other venues. Especially well known are the memoirs written by Hanna Nakkarah and Mohammad Nimer Hawari. ${ }^{8}$ Four files from Hawari's personal archives are open to the public (courtesy of his family) at the Mada al-Carmel - Arab Center for Applied Social Research in Haifa.

The article begins with some theoretical approaches to the study of professionalisation, which provides its conceptual framework. The second section presents a brief review of the licencing and professional training tracks for lawyers during the Mandate period. The next section examines the implications of the 1948 war for the Palestinian Arab legal community under the State of Israel. The fourth section 
analyses the circumstances that enabled some lawyers to continue their practice despite the new restrictions imposed by the state, as opposed to others, who succumbed to these restrictions and ceased practising law. The concluding section stresses the influence of this small professional group on wider developments in Israeli history.

\section{Conceptual framework}

Since its early days, Israel's state agents tried to limit the practice of Palestinian lawyers. As this study demonstrates, the latter's struggle to secure their freedom of occupation became a general conflict over the legal profession in Israel, involving various state agencies, as well as lawyers within the government apparatus and from the private sector. For the lawyers' representatives in state institutions and in the Israel Bar Association, this conflict was a step both in establishing the legal profession's autonomy from state control and in claiming exclusivity for their work as interpreters of the law. Our analysis is drawn from sociological scholarship on professionalisation that conceptualises the aims and strategies of professional groups. Michael Burrage, Conrad Jarausch and Hannes Siegrist suggest a theoretical framework that characterises four actors whose actions shape professionalisation and determine its success or failure: the professionals themselves, the state, the users (or clients) of these professional services and training institutions (such as universities). ${ }^{9}$ This characterisation is a convenient working tool, but an empirical historical study requires a more flexible, nuanced approach. Therefore, our discussion incorporates the work of other scholars who examine the interrelations and historical developments that shape professional groups.

This study reveals two factors that spurred the Jewish lawyers' leadership to actively object to discrimination against the Palestinian lawyers. The first was interference from non-professional outsiders. Andrew Abbott suggests that professions compete for work involving similar tasks. By claiming control over knowledge and skills, professional groups prevent others from entering their jurisdiction. ${ }^{10}$ Therefore, 'the interplay of jurisdictional links between professions determines the history of the individual professions themselves'. ${ }^{11}$ Exclusion is one common strategy used to 'deny to those who are not inside a privileged group access to some assets which give the group a monopolistic position on the market, or at least some sort of control over the market'. ${ }^{12}$ As this article demonstrates, when state officials tried to ban the Palestinians from legal practice, they faced resistance from several agents within the legal field. The latter resorted to exclusion in order to prevent non-professional interlopers from interpreting the law according to their agenda.

The second factor that motivated the Israeli legal profession's stance in the case of its Palestinian members was its interrelations with the state. A prominent aspect of these interrelations was the legal profession's striving for autonomy. Self-government is a basic aim of professional groups. It grants them control over entry to the profession and practice and enables them to enhance their corporate interests. ${ }^{13}$ Autonomy from state control also raises the profession's prestige and the social status of its members. In Israel's early years, striving for professional autonomy conflicted with etatist policy and strong collective and 
national sentiments. Terence Halliday and Lucien Karpik, comparing the legal profession in four national cases, propose that the autonomy of legal professions is historically tied to the rise of a liberal political system. In addition, the autonomy of the bar in a liberal political regime has the potential to constrict the power of the state and defend the liberty of other groups and citizens. ${ }^{14}$ Lawyers tend to protect a certain liberal core, but according to Halliday and Karpik, this is a narrow conception of liberalism that emphasises the rule of law and identifies the right of access to the judicial system as the main component of citizenship. Lawyers are generally less committed to (or even resist) extended political and social aspects of liberalism. ${ }^{15}$

Did this limited conception of liberalism also prevail among Israeli lawyers during the time under discussion? In her article examining the development of lawyers' ethos of public service in Mandatory Palestine and later in Israel, Neta Ziv argues that lawyers in nascent Israel had 'a rather weak professional commitment to ideas such as public service and professional social accountability'. The bar in this period 'did not further any substantive or normative platform, such as protection of individual rights, equality under the law or even equitable access to the justice system.' ${ }^{16}$ Our study shows that the bar association and the lawyers in the Ministry of Justice opposed a discriminatory policy against Palestinian lawyers on the basis of the rule of law and equal rights. Yet, although this reasoning disputes Ziv's assertion, a more comprehensive historical study of lawyers' public attitudes in nascent Israel is required to determine which sense of liberalism they were committed to, the broad or narrow version.

This conceptual framework enables us to observe the links between Palestinian lawyers' individual careers, their professional group, and some of the historical developments that constructed the status of minorities in Israel. In addition, this approach calls for a historical explanation that transcends evident national divisions and integrates a variety of positions, complex interests, and regional and global influences beyond the particular Israeli context.

\section{The legal profession in the Mandate period}

At the beginning of the Mandate period, there were fewer than a hundred lawyers in Palestine. These were mostly Arabs, who for the most part were without formal legal education. ${ }^{17}$ In the early 1920 s, the British promoted professionalisation by enacting an ordinance to regulate the profession ${ }^{18}$ and by opening a government law school known as the 'Jerusalem Law Classes.. 19

In 1938, the high commissioner enacted two ordinances ${ }^{20}$ in an effort to enhance the process of regulation. ${ }^{21}$ These ordinances, the Advocates Ordinance, 1938, and the Law Council Ordinance, 1938, remained in force (with minor changes) for the remainder of the Mandate period and beyond, into the early years of the State of Israel. They changed the legal profession by creating a closed group of attorneys with formal legal training who were permitted to engage in a specific profession and were listed in a register called the 'Roll of Advocates'. ${ }^{22}$ The Roll of Advocates was managed by the Law Council, whose duty it was to register only those who met the conditions set by law and to enforce the professional ethics of those already registered. ${ }^{23}$ 
Two types of legal professionals were registered in the Roll of Advocates: lawyers, who were qualified to conduct legal proceedings in civil courts, and religious scholars, who were similarly qualified to appear before Sharia courts. It was not uncommon to have both types of qualification. Regulations promulgated by the Law Council Ordinance determined who, with regard to any of these qualifications, was entitled to be registered in the Roll of Advocates. ${ }^{24}$

To register as a civil lawyer, one had to have reached the age of 25, submitted a 'certificate of good character', undergone a two-year internship, signed a written declaration, and finally, successfully passed a law exam. Only graduates of the Jerusalem Law Classes or graduates of a foreign institution approved by the Law Council were eligible to take this exam. Lawyers with practical experience in foreign countries and those who served in government legal or judicial positions before the law came into force were exempted from the internship requirement. ${ }^{25}$

Those wishing to register as being licenced to appear before a Sharia court were required to submit a certificate of good character, sign a written statement and submit either a certificate of completion of a course in Muslim law in the Jerusalem Law Classes or a certificate issued by the Supreme Muslim Council stating that the applicant was well versed in Sharia law. ${ }^{26}$

These regulations indicate quite a variety of lawyers during the Mandate: graduates of the Jerusalem Law Classes, Mandate government legal clerks and other officials and lawyers who had studied in a variety of foreign institutions, and religious scholars with knowledge of Sharia law. All of these lawyers practised law and created an eclectic legal culture affected by a wide variety of legal traditions. ${ }^{27}$

Registration on the Roll of Advocates was unified for the two classifications: civil and Sharia law. The same serial registration number was given for both types of qualification, and a person who was qualified in both types would have a single licence number. According to article 10 of the Advocates Ordinance, lawyers could renew their registration by paying an annual fee.

In addition to the Law Council, which was the statutory body responsible for lawyers' registration and enforcement of ethics, there existed voluntary associations of lawyers. The Jewish association was founded in 1928, and certain local Arab associations followed in Jaffa and Jerusalem. An attempt at forming a nation-wide Palestinian Arab association was made in the 1940s by veteran lawyer Abdul Latif Salah. ${ }^{28}$ These politically-oriented associations operated in the reality of the conflict between the Jewish and Palestinian Arab national movements, and both movements' struggle for independence from British rule. ${ }^{29}$

It is important to emphasise that the Arab and Jewish associations were voluntary: one could practise law without being a member of any of them. The authority in charge of licencing and supervising lawyers was the statutory Law Council. ${ }^{30}$ The bar association assumed the statutory power of the Law Council in 1961 and still serves as both a professional guild and a regulatory instrument for licencing and disciplining lawyers.

The Law Council under the Mandate was headed by the chief justice, president of the Supreme Court. This judge was always British, and neither a Jew nor an Arab had ever held the office. Licencing ceremonies were held a few times a year in small numbers of up to 20 new lawyers. The ceremony was a respectable event, duly covered in the newspapers. ${ }^{31}$ 
Full details of all lawyers listed in the Roll of Advocates, who had paid the annual fee and were licenced to practise law, were published annually in the official journal, The Palestine Gazette, in English, Arabic and Hebrew. The list included each lawyer's licence number, full name, type of qualification (civil, Sharia or both) and the address of their registered office, and it was publicised annually in the official gazette after the establishment of the State of Israel ${ }^{32}$ until the large number of lawyers rendered such a publication ineffective. ${ }^{33}$ This list is the main source of information regarding active lawyers during the years 1938-1962.

Our database of lawyers in Mandatory Palestine is based on a unification of the last two registers to appear before the outbreak of the 1948 war, ${ }^{34}$ published in the Official Gazette in English and Hebrew. ${ }^{35}$ The unified list includes 915 active lawyers: 692 were Jews and most of the rest were Palestinian Arabs. The last licence number in the 1947 list was 1,166 . The difference results from lawyers, who had retired, died, emigrated, were appointed to the judiciary, or whose licences had been revoked for one reason or another. The registered addresses allow us to locate the geographic spread of the lawyers. Most of the Palestinian Arab lawyers' offices were registered in the Palestinian Arab urban centres: Haifa, Tulkarm, Jaffa, Jerusalem, Nazareth, Gaza, Acre, Ramallah, Nablus, Lydda and al-Ramla. A smaller number of lawyers acted in towns such as Hebron, Safad and Beersheba. ${ }^{36}$ There were 110 Palestinian Arab lawyers registered at addresses within the 1949 Israeli borders. ${ }^{37}$ Of these, 39 were listed in Haifa, 37 in Jaffa, 10 in Acre, 5 in Nazareth, 5 in Safad, 4 in al-Ramla, 3 in Lydda, 2 in Beersheba, 1 in Tiberias and 1 in Fallujah.

In Arab towns (such as al-Ramla or Tulkarm), only Palestinian Arab lawyers were registered, while in Jewish Tel Aviv, only Jews practised law. But in some mixed cities, Jews and Arabs alike were registered. For example, Tiberias had 1 Arab and 4 Jewish lawyers, and Haifa had 159 lawyers, of whom 120 were Jews and 39 were Arabs. Jewish-Arab legal cooperation was not uncommon. Mixed partnerships did exist, as well as cross-community representation, estimated as high as 10 per cent. $^{38}$

The mixed city of Haifa is an interesting case for the study of the legal cultures and identities of lawyers near the end of the Mandate period. Jewish lawyers working in Haifa were among the founders of major law firms active until today, such as Salomon-Lipschutz. ${ }^{39}$ The community of Haifa lawyers also included some important legal personae such as future Members of Knesset (the Israeli parliament) David Bar-Rav-Hay, ${ }^{40}$ and Nahum Heth, ${ }^{41}$ and future Supreme Court Justice David Bechor. ${ }^{42}$ Arab lawyers in Haifa had also developed a legal culture with promising potential to take root. Among the active lawyers were members of notable families and known public figures such as Joseph Sahyoun, who later became the minister of information of the 'All Palestine' government, founded in Gaza in $1948{ }^{43}$ Wadi' Boustani and Abdel Karim El Karmi were also respected poets ${ }^{44}$; Mu in al-Madi and Subhi Khadra were two of the founders of the Palestinian Arab Istiqlal party $^{45}$ and Hanna Asfour represented the Palestinian Arab Workers Society. ${ }^{46}$

\section{Nakba ramifications on Palestinian lawyers' career tracks}

In November 1947, Jamil Labib Khoury, a Palestinian Arab licenced to practise law (registry no. 965), was appointed magistrate in Haifa. The Hebrew edition of the 
Palestine Gazette (issue 1630, 27 November 1947) announced that the high commissioner had appointed Khoury temporary magistrate at the Department of Courts, beginning 17 November 1947. Jewish and Arab magistrates presided side by side in the Haifa magistrate's court. At the time of Khoury's appointment, he was to serve with Judge Shimon Agranat, future president of the Supreme Court of Israel. ${ }^{47}$ Twelve days later the UN General Assembly adopted resolution 181. This resolution, which proposed a plan for dividing the territory of the Palestinian British Mandate into a Jewish and an Arab state, ending Mandatory rule, triggered the outbreak of the Jewish-Arab war. These political events foretold that Khoury's fate would be much different than that of his fellow Jewish magistrate. As Pnina Lahav writes, in the period that followed, 'Arab judges (the majority in the court) and Jewish judges were eyeing each other with anxious indignation. Each group was actively involved in the political struggle. Slowly, the majority of the Palestinian middle class began to pick up and leave. ${ }^{48}$ By 1949 , Khoury would find himself deposed from his position, trying to maintain a private legal practice in a city almost emptied of its Palestinian Arab residents. Agranat, who maintained his judicial position and continued to rise in the judicial hierarchy, would strongly insist, 'until the end of his life, that "no one forced them to go. They left"'.99

Only 20 per cent of the Palestinian Arabs who lived in the areas of the British Mandate that subsequently became the State of Israel remained as Israeli citizens after the 1948 war. The urban population, to which most lawyers belonged, fared even worse than the general statistics indicate. Entire cities, including the western neighbourhoods of Jerusalem and ancient cities such as Safed or Tiberias, were emptied of their Palestinian Arab populations. About 27 per cent of the Palestinian rural population in 1946 remained under the Israeli regime, while the urban population dropped to approximately 17 per cent. ${ }^{50}$

The population of lawyers suffered an even harder blow than the general urban population. Of the 110 Palestinian Arab lawyers who were registered in the 19461947 Roll of Advocates and whose registered office addresses were within the boundaries of the future State of Israel, only nine remained in 1952: 8 per cent. ${ }^{51}$ Given that some Palestinian Arab lawyers registered in Jerusalem might have practised in the western parts of the city, the figures might even be lower.

The 1952 list published in the official Israeli gazette Yalkut Hapirsumim ${ }^{52}$ was not the first register of lawyers published by the State of Israel: two lists had been published in 1949 and $1950 .^{53}$ However, the 1952 list reflects changes that occurred in the four years following Israel's establishment, such as revocation of the licences of a few lawyers and the emigration or repatriation of others. Table 1 presents preliminary biographical information of the 12 Palestinian Arab lawyers who were registered on at least one of the lists of the Law Council in 1949-1952 as well as on the 1947 list. Only nine of them appear in the 1952 list. The circumstances of the missing three lawyers will be discussed below.

The nine lawyers registered in 1952 had offices in Haifa and Nazareth. The flourishing lawyer communities of Jaffa, Acre and al-Ramla were annihilated. Only one of the Palestinian Arab lawyers who had a practice in Jaffa before 1948, Mohammad N. Hawari, was registered in 1952. Unable to return to reside in Jaffa, Hawari re-established his office in Nazareth. ${ }^{54}$ There was a big difference 
Table 1. Palestinian Arab lawyers who appear on the Mandate and Israeli Roll of Advocates (1947-1952)

\begin{tabular}{|c|c|c|c|c|}
\hline $\begin{array}{l}\text { Name as appears in } \\
1947 \text { list }\end{array}$ & $\begin{array}{l}\text { License } \\
\text { number }\end{array}$ & Office address & $\begin{array}{c}\text { Birth and death } \\
\text { dates }\end{array}$ & $\begin{array}{l}\text { Registers in } \\
\text { which he is listed }\end{array}$ \\
\hline \multirow[t]{4}{*}{ Amin Jarjoura } & \multirow[t]{4}{*}{271} & \multirow{4}{*}{$\begin{array}{c}\text { Haifa (1947) } \\
\text { Nazareth } \\
(1952)\end{array}$} & \multirow[t]{4}{*}{$1886-1975$} & 1947 \\
\hline & & & & 1949 \\
\hline & & & & 1950 \\
\hline & & & & 1952 \\
\hline \multirow[t]{2}{*}{ Subhi Ayyobi } & \multirow[t]{2}{*}{285} & \multirow{2}{*}{$\begin{array}{c}\text { Jaffa (1947) } \\
\text { Tel Aviv } \\
(1950)\end{array}$} & \multirow[t]{2}{*}{ 1902-1973 } & 1947 \\
\hline & & & & 1950 \\
\hline \multirow[t]{4}{*}{ Husni Zu'bi } & \multirow[t]{4}{*}{328} & \multirow[t]{4}{*}{ Nazareth } & \multirow[t]{4}{*}{$1902-1983$} & 1947 \\
\hline & & & & 1949 \\
\hline & & & & 1950 \\
\hline & & & & 1952 \\
\hline \multirow[t]{3}{*}{ Wadi' Boustani } & \multirow[t]{3}{*}{338} & \multirow[t]{3}{*}{ Haifa } & \multirow[t]{3}{*}{$1888-1954$} & 1947 \\
\hline & & & & 1949 \\
\hline & & & & 1950 \\
\hline \multirow[t]{4}{*}{ Elias N. Koussa } & \multirow[t]{4}{*}{355} & \multirow[t]{4}{*}{ Haifa } & \multirow[t]{4}{*}{$1897-1971$} & 1947 \\
\hline & & & & 1949 \\
\hline & & & & 1950 \\
\hline & & & & 1952 \\
\hline \multirow[t]{4}{*}{ George Mu'ammar } & \multirow[t]{4}{*}{384} & \multirow[t]{4}{*}{ Haifa } & \multirow[t]{4}{*}{$1898-1958$} & 1947 \\
\hline & & & & 1949 \\
\hline & & & & 1950 \\
\hline & & & & 1952 \\
\hline \multirow[t]{4}{*}{ Hanna Nakkarah } & \multirow[t]{4}{*}{518} & \multirow[t]{4}{*}{ Haifa } & \multirow[t]{4}{*}{ 1912-1984 } & 1947 \\
\hline & & & & 1949 \\
\hline & & & & 1950 \\
\hline & & & & 1952 \\
\hline \multirow[t]{2}{*}{ Issa Hazou } & \multirow[t]{2}{*}{529} & Haifa & (Unknown) & 1949 \\
\hline & & & & 1950 \\
\hline Tewfik B. Mu'ammar & 755 & Haifa & $1914-1988$ & 1947 \\
\hline & & & & 1949 \\
\hline & & & & 1950 \\
\hline & & & & 1952 \\
\hline Jamil Labib Khouri & 965 & Haifa & $1907-1986$ & 1947 \\
\hline & & & & 1949 \\
\hline
\end{tabular}


Table 1. (Continued.)

\begin{tabular}{|c|c|c|c|c|}
\hline $\begin{array}{l}\text { Name as appears in } \\
1947 \text { list }\end{array}$ & $\begin{array}{l}\text { License } \\
\text { number }\end{array}$ & Office address & $\begin{array}{c}\text { Birth and death } \\
\text { dates }\end{array}$ & $\begin{array}{l}\text { Registers in } \\
\text { which he is listed }\end{array}$ \\
\hline & & & & 1950 \\
\hline & & & & 1952 \\
\hline \multirow[t]{4}{*}{ Ali Sharif Zu'bi } & \multirow[t]{4}{*}{991} & \multirow{4}{*}{$\begin{array}{c}\text { Haifa (1947) } \\
\text { Nazareth } \\
(1952)\end{array}$} & \multirow[t]{4}{*}{ 1917-2007 } & 1947 \\
\hline & & & & 1949 \\
\hline & & & & 1950 \\
\hline & & & & 1952 \\
\hline \multirow{2}{*}{$\begin{array}{l}\text { Mohammad Nimer } \\
\text { Hawari }\end{array}$} & \multirow[t]{2}{*}{1003} & \multirow{2}{*}{$\begin{array}{c}\text { Jaffa (1947) } \\
\text { Nazareth } \\
(1952)\end{array}$} & \multirow[t]{2}{*}{ 1908-1984 } & 1947 \\
\hline & & & & 1952 \\
\hline
\end{tabular}

between Nazareth and Haifa, where Palestinian lawyers had their practices after 1948. Haifa lost most of its Palestinian inhabitants during the Nakba, while Nazareth's population increased as many refugees settled there.

In the mixed city of Haifa, the Palestinian Arab population numbered about 70,000 at the end of the Mandate period. This figure represented about 48 per cent of the total number of residents, both Jews and Arabs. ${ }^{55}$ There were violent clashes between Jews and Palestinians in Haifa for several months, during which time there was a gradual departure of the Palestinian Arab civilian population. Haifa was an important administrative, economic and logistics centre for the British authorities, and many of those who remained believed that as long as the British remained in the city and constituted a barricade between the warring parties, no harm would befall them. When the British announced in April 1948 that they intended to evacuate their strategic facilities in the city ahead of the final withdrawal of the British army, which was supposed to take place in August, the Palestinian Arab leadership realised that the fate of Arab Haifa had been sealed, and they left town. With the full takeover of Haifa by Jewish Haganah ${ }^{56}$ forces in April 1948, most of the remaining civilian population fled, mainly by sea. In 1951, there were 7,500 Palestinian Arab residents of Haifa, a mere 10 per cent or so of the original population. ${ }^{57}$

Two of Haifa's Palestinian Arab lawyers, Elias Koussa and George Mu'ammar, were members of the National Committee that managed Palestinian Arab affairs in the city until it was taken over by the Haganah. ${ }^{58}$ They were also members of the delegation representing the Palestinian Arabs in Haifa in the negotiations over a ceasefire agreement following the dissolution of the National Committee. ${ }^{59}$ In his memoirs of those difficult days, as told to the Jewish writer Haviv Kna'an, Koussa recounted: 'I suddenly found out that I am one of the prominent figures of the Haifa Arab public'. ${ }^{60}$ Thus, with a sense of astonishment, Koussa expresses the vacuum created in local political life, which he and other lawyers were drawn to fill. ${ }^{61}$ Eventually, of the 39 Palestinian Arab lawyers who worked in the city in 1946-1947, only eight were still registered in 1952 - about 20 per cent. 
Nazareth was an Arab town, devoid of Jewish residents, located in the heart of the area destined, according to UN resolution 181, to be part of the Arab state in the Galilee area. Although the town served as the headquarters of the Arab Liberation Army, ${ }^{62}$ the war did not reach Nazareth until July 1948, when it was captured without a fight. The Arab Liberation Army retreated, leaving the city and its population at the IDF's mercy. After the occupation, Israeli premier David Ben-Gurion ordered that the residents not be deported, probably because of the city's sacred status in Christianity. ${ }^{63}$ The city was also a refuge for many Palestinian Arabs who fled the war from different regions of the Galilee. After the Israeli conquest, some of the Nazareth residents who had fled the city were allowed to return. In sum, Nazareth's pre-war population increased by about 30 per cent, from 15,540 in 1946 to 20,300 in $1951 .^{64}$ The relatively safe situation in Nazareth was probably one of the reasons why five of the nine lawyers active in 1952 had their offices registered there. ${ }^{65}$

The 12 lawyers at the focus of this research faced the war and its upheavals in various ways. Some remained continuously in their homes, even after the area was taken over by Jewish paramilitary forces or by the IDF. Some of them found temporary refuge in a neighbouring state or in areas designated to become part of the Arab state according to the UN partition plan. They returned to Israeli territory in a variety of ways: Mohammad N. Hawari was allowed by the Israeli government to return in 1950, apparently for political reasons. ${ }^{66}$ Hanna Nakkarah, who was in Acre when Haifa was taken over by Haganah forces, fled to Lebanon and returned by plane via Cyprus. Upon arrival, he was arrested as an infiltrator, spent over three months in prison, and it took a public political campaign to get him released and avoid his deportation. ${ }^{67} \mathrm{He}$ was not granted full citizenship until a few years later, and only a petition to the High Court of Justice enabled him to acquire an Israeli passport. ${ }^{68}$ Subhi Ayyobi fled Jaffa (which was a war zone before its final occupation by Jewish forces) to the village of Jaljuliya, an area designated in the partition plan to be part of the Arab state. Jaljuliya, however, was transferred to Israeli sovereignty as part of the border adjustments in the Rhodes ceasefire agreements in 1949, ${ }^{69}$ and Ayyobi found himself in the territory of the State of Israel. ${ }^{70}$ As Nakkarah's petition to the High Court demonstrates, the return to that territory did not guarantee full citizenship. ${ }^{71}$ It took legal effort, sophistication and initiative to remain in Israel as a citizen, as the state had taken strict legal measures to prevent the return of departed Palestinian Arabs. After securing their civil status, the Palestinian lawyers turned to securing their living. They were eager to continue practising law even in the new reality. As we shall see, this too could not be taken for granted.

\section{Practising law in the Jewish state}

Ostensibly, there was no legal impediment preventing Arab lawyers listed in the Mandate Roll of Advocates from continuing to practise law in the newly established State of Israel. The new state's first legislative step was the enactment of the Law and Administration Ordinance (LAO). Section 11 of the LAO determined that the law that was in effect during the Mandate period would remain in effect. Mandate laws did not usually distinguish between Jews and Arabs. Indeed, Mandate law included 
provisions discriminating against Jews in the context of land acquisition and immigration, but these were declared null and void by the LAO; formally, the law including the Advocates Ordinance and the Law Council Ordinance - did not specify any ethnic exclusion. But in reality, in the first years of the State of Israel, the mere word of the law was not enough to guarantee equal rights for Palestinian Arab citizens.

Though Israel guaranteed its Palestinian citizens equality, with suffrage rights and formal freedom to engage in any occupation, the Palestinian Arab population was subjected to the military rule imposed by extensive use of emergency regulations, mainly inherited from the Mandate legislature through article 11 of the LAO. The main use of these regulations was to reduce these citizens' freedom of movement. Palestinian Arab population centres were declared military zones: their residents could not exit them without a permit from the local military commander. It is clear that a lawyer who lived, for example, in Acre, and worked in Haifa, would not have been able to practise freely, and his potential clientele was not free to consult him at his offices. In fact, his professional fate would lie in the hands of the military commander of his zone (although the geographical area of the military zone was reduced, and the mixed cities were excluded from it at a very early stage). ${ }^{72}$

The military rule had more indirect ways to disrupt Palestinian lawyers' practices. In a letter dated 10 December 1950, Lieut. Colonel Emmanuel Mor, head of the military rule, instructed his subordinates to prevent, as much as possible, the representation of Palestinians by lawyers, by 'making the Arabs realise that being represented by a lawyer does not achieve any goals and will result in merely a waste of money'. He further instructed the military governors to never make any commitments to a lawyer and to avoid issuing a lawyer any written document without his prior approval. ${ }^{73}$

A powerful state official who showed interest and involvement in the lives of the Palestinian Arab lawyers in Israel held the newly formed post of 'prime minister's advisor on Arab affairs', Yehoshua (Josh) Palmon. This post was created in 1949 and Palmon, a former member of the Haganah Intelligence Services, was appointed. He had a decisive influence on various decisions made regarding almost every aspect of the lives of Palestinian Arabs in Israel. ${ }^{74}$ Palmon had a firm opinion regarding Palestinian Arabs practising law, as will be demonstrated below.

Palestinian lawyers in Israel faced another problem: the Arab Bar Association had ceased to exist, and the Jewish association declared itself 'The Israel Bar Association' ${ }^{75}$ Before the Israel Bar Law was enacted in 1961, one could practise law without belonging to an association (and many did so), but association membership was beneficial, and Palestinian Arab lawyers wanted to join the Israel Bar Association. Palmon, however, strove to prevent this.

The matter of Palestinian Arabs practising law was brought to Palmon's attention in the summer of 1949: Subhi Ayyobi, a wealthy, successful lawyer, objected to the travel restrictions imposed upon him by the military rule and appealed to the Supreme Court. ${ }^{76}$ The case, supported by a political campaign initiated by leftist parties, received media coverage. ${ }^{77}$ Ayyobi, who had been active in the Palestinian Arab leadership in Jaffa since the late $1920 \mathrm{~s},{ }^{78}$ had had a legal practice there before the war. As Jaffa turned into a heavily bombarded war zone, he went to Ramallah, 
and from there he moved to a property he owned in Jaljuliya, which was located in the territory designated for the Arab state under the partition plan. But in 1949, this area was transferred to Israel as part of the Rhodes agreements. Owing to the movement restrictions of the military rule, Ayyobi found himself trapped in Jaljuliya, at the time a small village that was very different from the flourishing urban centre of Jaffa. Apparently, he was unable to support a legal practice there, and after his property in Jaljuliya was robbed, he decided to leave the village. He obtained a permit to leave for Jaffa for emergency medical treatment. After his medical condition improved and the permit expired, he did not return to Jaljuliya as required but moved permanently to Jaffa, regained his licence to practise law, and opened a law firm in Jaffa (that was annexed to Tel Aviv municipality). Apparently, he also managed to reclaim some of his assets that had been declared absentees' property and had been effectively confiscated by the state. ${ }^{79}$

According to the correspondence between Palmon and parties in the Israel Bar Association and the Office of the Attorney General, Palmon considered Ayyobi's behaviour scandalous. As Ayyobi himself was 'taken care of by the military authorities, which issued a special warrant commanding him to return to Jaljuliya, Palmon decided to operate on a general level and use Ayyobi's case to push for steps to be taken against Palestinian Arab lawyers in general. He acted to prevent lawyers from being accepted as members of the Israel Bar Association, and he promoted the enactment of regulations that would severely limit or even prevent the practice of law by Palestinian Arabs.

In a series of letters he wrote to the various parties, Palmon expressed his concerns regarding Palestinian Arabs practising law. ${ }^{80}$ His main argument was that these lawyers might successfully appeal to the High Court of Justice against the arbitrary actions of the military government and thereby thwart government moves that were on the edge of legality. This can be concluded from Palmon's response to the case of Yusuf Emil Bayruti, a merchant from Jaffa, who was under the legal status of 'absentee' when he entered Israel, and was therefore about to be deported. When Bayruti threatened to file an injunction against his deportation, the attorney general decided not to deport him, fearing the court would issue a precedential ruling in favour of Bayruti that would enable the return of many refugees. Palmon wrote to the attorney general: ${ }^{81}$

Should we agree that any lawyer - whatever may be the reasons that motivate him to act, the matter itself, or economic interest - will raise questions and open up trials against the government that will lead to the government's withdrawal and concession because the government would not want to publicly display that its actions have no legal validity? Attorney Schwartz's threat that he will issue an injunction if we do not cancel the deportation of Emil Bayruti, who entered Israel illegally, has had an undesired effect. At the attorney general's request, we have not deported Bayruti, because we had no interest in a high court ruling that any refugee from Eretz Yisrael could reenter Israel and remain in it, since the Immigration Law does not allow for his deportation.

There are a multitude of examples. And if we do everything in our power, in administrative and other ways, to prevent the submission of appeals on Arab affairs, we do not do so because of harassment or a desire to cover up the 
authorities' harmful acts against Arabs, but rather to compensate for the legislator's failure in meeting the needs.

Palmon's position was accepted with unease among the jurists. The argument that there is something wrong with petitioning the High Court of Justice since it is liable to prevent the government from acting as it pleases, sounds harsh to the legal ear. It can be assumed that lawyers who were used to a reality in which Jewish and Arab lawyers argued as equals before a court in which Jewish and Arab judges presided and gave rulings based on the merit of the arguments and not on ethnicity, could not contemplate why Palestinian Arab lawyers could not continue their practice. In these years, judges and lawyers perceived their public role to be one of constructing the basic elements of a liberal democracy and emphasising the rule of law. ${ }^{82}$ Oren Bracha, examining the Supreme Court's attitude towards 'infiltrators' in the early days of the state, argues that judges rarely criticised the state in those cases. But when they chose to take a critical stand against the executive power, they did so in an effort to establish the rule of law in a society that historically tended towards non-legalism and disregard of the law. ${ }^{83}$ Lawyers shared these notions. As we shall see, the response of their representatives in the bar association and in the Ministry of Justice emphasised equality and the rule of law and served as a brake on Palmon's approach.

It is also plausible that the jurists saw Palmon's pressure as interfering with their professional autonomy, and that they opposed it as part of their demand for selfgovernment, free from control by others. Part of the legal profession's prestige is based on its claim of autonomy and a monopoly on services. ${ }^{84}$ From this point of view, Palmon represented the state's excessive restrictions on legal jurisdiction. Moreover, the lawyers regarded themselves as the proper interpreters of the law: Palmon was an interloper.

Thus, the bar association initially decided to approve the acceptance of Palestinian Arabs into its ranks but postpone the implementation of the decision until after it had conducted a thorough consultation with the minister of justice, the attorney general, the prime minister's advisor on Arab affairs (Palmon) and the Foreign Ministry. Apart from Palmon, none of the others shared the view that Palestinian Arabs should not be allowed into the ranks of the Association. ${ }^{85}$

Finally, the Israel Bar Association announced the following decision:

A. There is to be no discrimination in accepting a lawyer into the association in terms of race, nationality or religion.

B. A prerequisite for each new member is to have the right to permanent residence in the country as a whole. ${ }^{86}$

Section B appears to follow Palmon's logic, as it would have prevented accepting lawyers like Hanna Nakkarah, who returned to Israel after the war and had their right to remain in it questioned. However, the section was merely a restatement of section 19 of the Advocates Ordinance, according to which, 'a person holding a practising licence shall be entitled to practise so long only as he is resident of Palestine'. It is clear that if someone is not a legal resident, and cannot practise law, there is no reason for him to be a member of the bar association. 
Palmon did not accept the decision favourably, warning the members of the Israel Bar Association that they should beware of Arab lawyers who would try to turn their occupation into a legal way to circumvent the military government regulations - that their ranks would be filled with 'unwanted lawyers, due to their past and activities in the time of the Mandate. ${ }^{87}$

But this failure did not deter Palmon, and he continued trying to bring about a legislative amendment that would prevent Palestinian Arab lawyers from practising law. In a series of letters dating from the end of 1949 until the middle of 1950, Palmon corresponded with the staff of the attorney general's office. He met with the determined opposition of newly appointed Attorney General Haim Herman Cohen, and Deputy Attorney General Zvi Eli Baker. Baker did not spare words in expressing his opposition to Palmon's ideas, and he received the full support of Attorney General Cohen, who later became one of the leaders of the liberal line in the Supreme Court. It stands to reason that he too did not favour Palmon's approach.

Palmon asked whether there was a legal basis for granting a lawyer's licence to an attorney who had infiltrated the country but was not yet expelled from it, or was found in the 'occupied territory' (transferred to Israel under the Rhodes agreements) ${ }^{88}$ Baker replied that there was no way to prevent any lawyer from practising law if he paid the annual registration fee. In fact, from the moment of payment, the authorities were required to grant him the licence, there is no discretion in the matter, since according to article 10 of the Advocates Ordinance, a lawyer 'upon payment of such fee, shall [emphasis in the original] be granted a practising licence'. ${ }^{89}$

This answer clarifies that Baker viewed the subject as not only a debate about the status of minorities in Israel but also a professional issue. It seems that both Baker and the Israel Bar Association viewed Palmon's requests as an unwelcome interference in their professional jurisdiction. Thus, Baker used the ultimate professional skill and invoked the jurists' monopoly regarding the interpretation of the law, an argument that could not be countered by Palmon, who was a mere government official without any legal background.

However, Palmon remained unsatisfied, demanding to know whether regulations could be enacted under which an attorney living in a 'military zone' would not receive a licence without the consent of the military commander. In a comprehensive reply, Baker made it clear that this was not possible since the Law Council Ordinance and the Advocates Ordinance did not enable the enactment of such a regulation, once again using legal arguments based upon interpreting a way to restrain Palmon's unwelcome interference. Baker explained that the minister of defence could enact emergency regulations for this purpose, but that there was no point in doing that, since existing regulations allowed the military commander to prevent a lawyer from leaving the military zone, thereby effectively preventing him from practising law. Baker ends his letter with the following:

My opinion is that we must insist that the military rule authorities use the above powers towards people, including lawyers registered in the Roll of Advocates, only if the security circumstances require their use. It is possible that in the particular case that was before the Advisor on Arab affairs - lawyer Subhi Ayyobi - the military rule authorities feared that this veteran and 
experienced lawyer would contact Arabs in Jaffa and harass the government by defending the Arabs against the government's infringements, imagined or real, of their rights. If the purpose of the control the military rule authorities wish to establish is merely to prevent Arab lawyers from appearing in courts, it has to be strongly opposed, as it inflicts a serious and unjustified injury to the status of the lawyer, and may prevent imposing justice in the state. ${ }^{90}$

Baker's attitude was fully supported by Attorney General Haim Cohen. Their objection to Palmon's demand was once again based on a claim of exclusivity of jurists in interpreting the law. In a letter to Palmon, Cohen says that the type of legislation that Palmon demands is beyond Cohen's authority, but he intends to bring Ayyobi's case before the Law Council and to initiate an inquiry against him under article 20 of the Law Council Ordinance. ${ }^{91}$ This article enables the Law Council to form a 'committee of inquiry' and according to its findings take disciplinary action (including revoking a licence) against a lawyer who had committed a disciplinary offence. The members of this inquiry committee were, of course, lawyers.

As it turned out, there was no need to take disciplinary action against Ayyobi. On 2 March 1950, the military commander of the 'Central Zone', which included the village of Jaljuliya, issued a warrant forbidding Ayyobi from leaving the village. Ayyobi petitioned the High Court of Justice against the warrant, and his petition was denied on 26 May $1950 .{ }^{92}$ During the trial, Ayyobi's lawyer tried to ask the military commander what the security reasons for the restrictive warrant were. The commander refused to answer. The court had approved the restrictive warrant without anyone, other than the officer who signed it, knowing the security reasons behind its being issued.

Ayyobi immigrated to Libya in late 1951 and was appointed a district judge there. Libya gained independence in 1951, and this change in international circumstances was perceived as an opportunity by some Israeli officials, Palmon included, to devise a plan to encourage Palestinian Arabs to immigrate to Libya. Ayyobi's emigration was considered an instance of the success of this plan, though it failed to encourage emigration on any significant scale. ${ }^{93}$

The court's ruling in the Ayyobi case demonstrates some of the difficulties encountered by Palestinian lawyers who tried to maintain their practices in Israel during the early 1950s. The methods used to limit these lawyers were clear and included restrictive warrants issued by the military commanders, attempts to expel the lawyers on the grounds that they did not enter the state legally, and of course, the proceedings of the 'commission of inquiry' of the Law Council. These actions were taken against some of the lawyers, sometimes successfully. Hanna Nakkarah was arrested, and his citizen's status was uncertain. Only a petition to the High Court of Justice succeeded in granting him full citizenship status. ${ }^{94}$ A number of complaints were filed against Mohammad N. Hawari, one of them initiated by Prime Minister Ben-Gurion and IDF Chief of Staff Yigael Yadin. ${ }^{95}$ Hawari and Nakkarah overcame the proceedings against them and continued their professional practice, but some others did not: Issa Hazou is not registered on the Roll of Advocates after 1950; George Mu'ammar effectively terminated his legal practice at about that time; Wadi' Boustani migrated to Lebanon in 1953, 
joining his son who resided there, and died soon thereafter ${ }^{96}$; and according to one newspaper, Ali Sharif Zu'bi's licence was revoked in 1953 after he was found guilty of forging a power of attorney (although there is evidence he continued practising in 1952 and 1953). ${ }^{97}$ He immigrated to Jordan, where he maintained his firm and also embarked on a political career.

A Supreme Court ruling from 1951 reflects an additional procedure against a Palestinian Arab lawyer, whose name was withheld, revealing some of the opposing forces in play. ${ }^{98}$ The lawyer in question left Haifa during the war and fled to Nazareth. Upon his return, in November 1948, he found that his offices were occupied by people who were living there..$^{99}$ He was forced to rent an office from a man named Kanawati and pay him a quarter of his income. This rental transaction contradicted the Advocates Ordinance prohibiting a lawyer from sharing his income with a non-lawyer. The anonymous lawyer was questioned by the police Criminal Investigations Unit, and it is likely that the police filed the complaint against him with the Law Council. The Law Council, whose members were mostly lawyers (including Zvi Baker and Haim Cohen) had given the anonymous lawyer a very light punishment, a reprimand (that did not affect his ability to practise law and so did not harm or endanger his livelihood), thus providing a level of protection. He appealed to the High Court of Justice and was acquitted of all charges. The Supreme Court, thus, provided the lawyer with another layer of protection against what may have seemed an abusive and harassing police procedure.

Given that the population of lawyers in question included 12 lawyers, five cases represent a high rate of legal proceedings and withdrawal from the profession. One can assume that this was not a random occurrence.

\section{Conclusion: beyond the professional footprint}

Some of the survivors, the lawyers who succeeded in maintaining a practice after the early 1950s, reached influential positions and became leaders in their community. Some of them joined the Israeli establishment in significant roles - Amin Salim Jarjoura served as a member of the Knesset (1949-1951), ${ }^{100}$ Husni Zu'bi was the first qadi appointed by the State of Israel, Mohammad Nimer Hawari served as a district judge, and Jamil Labib Khoury was elected head of a local council. Their actions affected Israeli society as a whole, beyond the scope of their aim to advance the interests of their community.

For the first two decades of the State of Israel, Palestinian lawyers appeared before the Supreme Court, in endless battles over land expropriations and civil rights. These struggles left their mark on Israeli law. A prime example is the Supreme Court's ruling on the case of the Communist newspapers Kol Ha'am and al-Ittihad, which were closed by order of the minister of the interior as a sanction for criticising the government's pro-American policy. Hanna Nakkarah represented the editors of al-Ittihad. ${ }^{101}$ The ruling, in this case, constitutes one of the basic anchors for securing freedom of speech in the Israeli legal system, which is devoid of a written constitution. ${ }^{102}$

Another example is the struggle during the enacting process of the Law of Prescription in 1958. The 1957 Prescription Bill appeared to be designed to deprive Palestinian farmers of rights to the land they had customarily cultivated without a 
legal deed. ${ }^{103}$ Hanna Nakkarah and Elias Koussa represented the Palestinian farmers before a Knesset subcommittee that debated the bill, and their appearance was instrumental in shaping the final form of the law in a way that narrowed the state's ability to dispossess Palestinians of their rights to land. ${ }^{104}$ These clauses of the Prescription Law are still in force today. These two legal campaigns illustrate the importance of this group in Israeli legal and political history.

It is clear from this study that the Israeli government tried to set limits on the professional work of Palestinian lawyers. These efforts proved successful in at least two cases, those of Subhi Ayyobi and Ali Sharif Zu'bi. However, some Palestinian lawyers maintained their practices and became influential figures in the Israeli legal arena. Their personal and professional survival in the State of Israel, practising the profession for which they trained, required legal sophistication, activism, initiative and willpower. By bringing their own personal cases, and those of their Palestinian clients, before the court, they sometimes managed to expand the space of freedom and rights of Israel's Palestinian citizens during the country's early, formative years. They thus participated in both shaping the discourse of civil rights and restraining state power. The legal profession, as much as it may be the loyal servant of any establishment, can produce subversive mechanisms that expose the weak points in any system, legal or political.

The Palestinian lawyers' struggle was sometimes assisted by a powerful ally. Jewish lawyers in the private sector and in public service joined the Palestinian lawyers' struggle as part of their effort to enhance the rule of law and professional autonomy. The Jewish lawyers' agents employed a strategy of exclusion not against their Palestinian colleagues but against the state official who demanded the Palestinian lawyers' exclusion: Josh Palmon. This strategy enabled legal professionals to claim their jurisdiction and their professional monopoly as sole interpreters of the law.

Acknowledgements. Research for this study was supported by the Israel Science Foundation (grant no. 1831/18), which we acknowledge with gratitude. We are grateful to Iris Agmon and Irit Ballas for their valuable suggestions, and to Fady Asleh for sharing information and for his help in locating some of the documents quoted here. Finally, we thank the anonymous readers of Continuity and Change for their helpful comments.

\section{Notes}

1 The historical scope of this article is the British Mandate of Palestine and the first decades of the State of Israel. During the Mandate period, Palestinian subjects - Jews and Arabs - could be referred to as 'Palestinians'. However, in recent decades, the term 'Palestinian' has been used to denote only Palestinian Arabs.

2 For the sake of comparison, it is possible to present the numerical data relating to Jewish lawyers. The number of Jewish lawyers registered with the Jewish Bar Association (a voluntary body that incorporated Jewish lawyers during the Mandate period and that after the establishment of the state became the Israel Bar Association) rose, between January 1947 and May 1949, from 578 to 653, an increase of more than 12 per cent. See 'Report from the 13th conference of the Israel Bar Association', Hapraklit 6 (1949), 107. 3 The Nakba (Arabic for Catastrophe) is the name given to the 1948 war and its aftermath in Palestinian historiography and narrative.

4 For the damage caused to the Palestinian Arab urban population, and its deliberate neglect in Palestinian Arab historiography after 1948, see Manar Hasan, 'Destruction of city and the war on memory: the winners and the defeated', Teoriya u-viqoret 27 (2005), 197-207 (Heb.). 
5 Assaf Likhovski, 'Arab jurists and French identity in Mandate Palestine', Mehqarey mishpat 25 (2009), 213-35 (Heb.).

6 Donald M. Reid, Lawyers and politics in the Arab world, 1880-1960 (Minneapolis, 1981).

7 For example, George Emile Bisharat, Palestinian lawyers and Israeli rule: law and disorder in the West Bank (Austin, 1989), 26; Eli Salzberger refers to the bar association as 'Jewish' in parenthesis but fails to mention its Arab counterpart. Eli Salzberger, 'The Israeli jurists' conspiracy - on the Israeli Bar and its allies', Mishpatim 32 (2001), 46. Yehoshua Rotenstreich briefly mentions the Arab association but claims it was 'merely formal'. Yehoshua Rotenstreich, 'On the founding of the Israeli Bar Association', Hapraqlit, special issue commemorating 25 years of the Israel Bar Association (1987), 37.

8 Hanna Nakkarah, Memories of a Palestinian lawyer, 2nd edn (Beirut, 2011) (Ara.); Mohammad Nimer Hawari, The secret of the Nakba (Nazareth, 1955) (Ara.). In this article, we retained the spelling of the 1947 'Roll of Advocates' list throughout the article for names appearing on that list.

9 Michael Burrage, Konrad Jarausch, and Hannes Siegrist, 'An actor-based framework for the study of the professions', in Michael Burrage and Rolf Torstendahl eds., Professions in theory and history: rethinking the study of the professions (London, 1990), 203-25.

10 Andrew Abbott, The system of professions (Chicago, 1988).

11 Ibid., 20.

12 Rolf Torstendahl, 'Essential properties, strategic aims and historical developments: three approaches to theories of professionalism', in Burrage and Torstendahl eds., Professions in theory and history, 49.

13 Burrage, Jarausch, and Siegrist, 'An actor-based framework', 207.

14 Terence C. Halliday and Lucien Karpik, 'Politics matter: a comparative theory of lawyers in the making of political liberalism', in Terence C. Halliday and Lucien Karpik eds., Lawyers and the rise of western political liberalism (Oxford, 1997), 21.

15 Ibid., 17, 42-3, 51. Barzilai makes a similar claim regarding lawyers in Israel, but his study is contemporary, not historical. See Gad Barzilai, 'The ambivalent language of lawyers: between liberal politics, economic liberalism, silence, and dissent', in Terrance Halliday, Lucien Karpik, and Malcolm Feeley eds., Fighting for political freedom: comparative studies of the legal complex and political liberalism (Oxford, 2007), 247-77.

16 Neta Ziv, 'Combining professionalism, nation building and public service: the professional project of the Israeli Bar, 1928-2002', Fordham Law Review 71 (2003), 1632 and 1639, respectively. It should be noted that the paper refers almost solely to Jewish lawyers.

17 For a detailed review of the state of the legal profession in late Ottoman and early Mandate Palestine, see Bisharat, Palestinian lawyers, 18-31.

18 The Advocates Ordinance, 1922.

19 Assaf Likhovski, Law and identity in Mandate Palestine (Chapel Hill, 2006), 25; Bisharat, Palestinian lawyers, 23.

20 In the Mandate period and the very early days of the State of Israel, statutory laws were referred to as 'ordinances', as they were enacted by nonelected officials (the High Commissioner in the time of the Mandate, or the Provisional State Council, in the early Israeli period). Only after the first Knesset was established were these legislations referred to as 'laws'.

21 The Advocates Ordinance of 1938 was a revised form of the Advocates Ordinance of 1922 that was an earlier attempt at regulation and 'Anglocization' of the legal profession. See Ziv, 'Combining', 1625.

22 The term 'advocate' is from the French avocat or the Italian avocato. The Egyptian Advocates Law of 1893 used it to denote a prestigious group of lawyers who appeared before the 'mixed courts', a court system superior to the 'national courts'. See Farhat J. Ziadeh, Lawyers and the rule of law and liberalism in modern Egypt (Stanford, 1968), 34.

23 See Bisharat, Palestinian lawyers, 24.

24 Law Council Regulations, 1938.

25 These conditions were listed in art. 2 of the Law Council Regulations.

26 The Supreme Muslim Council was the official representative body of the Muslim community in Palestine during the Mandate period. The conditions for registry as a Sharia lawyer were listed in art. 6 of the Law Council Regulations.

27 Ron Harris, 'Chaim Tzadok as a jurist, a legislator and a minister of justice', in Ron Harris ed., Next to law's cradle (Jerusalem, 2002), 18 (Heb.).

28 Reid, Lawyers and politics, 315. 
29 Neta Ziv, Who will guard the guardians of law (Tel Aviv, 2015), 50 (Heb.).

30 The Law Council was empowered to form ad hoc committees to investigate complaints against lawyers, and if it found the complaints to be substantiated, it could use a number of disciplinary measures ranging from reprimand to dismissal from the profession. See Mutaz M. Qafisheh, 'Ethics of the legal profession in Palestine,' Fordham International Law Journal 42 (2019), 557-8.

31 'Seven new lawyers called to the Bar', The Palestine Post, 30 January 1942, 3.

32 In the Israeli period, this government publication was called Yalkut Hapirsumim (Hebrew for 'the collection of publications').

33 The last list was published in 1962, in No. 913 Yalkut Hapirsumim, 28 February 1962.

34 A list published during the war, in issue no. 1663 of the Palestine Gazette, on 22 April 1948, is not taken into account, as it obviously fails to represent the actual situation on its publication date, owing to the chaotic and fluid circumstances created by the war.

35 The last publication containing the list of active lawyers before the outbreak of the 1948 war appeared in issue no. 1557 of the English version of the Palestine Gazette, published on 27 February 1947. The last Hebrew list was published on 21 February 1946, in issue 1392 of the Hebrew version of the gazette. The two lists do not overlap exactly. Naturally, some lawyers were removed from the list between 1946 and 1947 , for various reasons such as retirement or death. There were also lawyers who received their licences between the two dates and were thus added to the 1947 list. But some lawyers with low licence numbers (those licenced earlier), appeared on the 1947 but not the 1946 list. Some appeared on the 1946 list, were absent from the 1947 list, and reappeared on later lists. To get a complete picture of the law practitioners just before the 1948 war, those whose names appear on both lists must be taken into account.

36 Today some of these cities and towns are within the territory of the State of Israel, and some are in the West Bank and the Gaza Strip. Haifa, Jaffa, west Jerusalem, Nazareth, Acre, Lydda, al-Ramla, Safed, Beersheba and Fallujah are in Israel. Tulkarm, east Jerusalem, Ramallah, Nablus and Hebron are in the West Bank. Gaza and Khan Younis are in the Gaza Strip.

37 Those registered in Jerusalem are not included in this figure, as the list does not distinguish lawyers who practised in the eastern parts of the city (an area not included in the territories controlled by the State of Israel in 1949) from those who practised in the western parts who left (or were deported) during the 1948 war. 38 Likhovski, Law and identity, 26.

39 Shuki Sadeh, 'When money in politics was measured in Lira', Haaretz, 20 May 2009, available at http:// www.haaretz.co.il/misc/1.1261733 (Heb.) [accessed 13 July 2020].

40 David Bar-Rav-Hay, The Knesset website, available at https://main.knesset.gov.il/mk/pages/MkPersonal Details.aspx?MKID=313 [accessed 13 July 2020].

41 Nahum Heth, The Knesset website, available at https://main.knesset.gov.il/mk/pages/MkPersonalDetails. aspx?MKID=426 [accessed 13 July 2020].

42 David Bechor, The Judicial Authority, available at https://judgescv.court.gov.il/7b8384ba-645e-e8118105-0050568a6817\%D7\%93\%D7\%95\%D7\%93-\%D7\%91\%D7\%9B\%D7\%95\%D7\%A8 [accessed 13 July 2020].

43 Mustafa Kabha, The Palestinians - a people dispersed (Raanana, 2010), 139 (Heb.).

44 Suleiman Jubran, 'Wadi' al-Boustani: a Palestinian poet from Lebanon', Al-Karmil 23-24 (2002-2003), 49 (Ara.); Kabha, The Palestinians, 99-101.

45 Weldon C. Matthews, Confronting an empire, constructing a nation: Arab nationalists and popular politics in Mandate Palestine (London, 2006), 140.

46 Zachary Lockman, Comrades and enemies (Berkeley and Los Angeles, 1996), 205.

47 Pnina Lahav, Justice in Jerusalem: Chief Justice Agranat and the Zionist century (Berkeley and Los Angeles, 1997), 65.

48 Ibid., 73.

49 Ibid., 75.

50 Charles S. Kamen, 'After the catastrophe I: the Arabs in Israel, 1948-1951', Middle Eastern Studies 23, 4 (1987), 458.

51 Mahmud El Madi, a veteran lawyer from Haifa, appears on the 1947 list but reappears only in the 1958 list, meaning that he did not practise law for over a decade. For this reason, El Madi will not be considered among the lawyers' group discussed in this article. Similarly, an Armenian lawyer, Ohannes Merguerian, listed in the 1946-1947 Roll of Advocates, had a practice in west Jerusalem after 1948. However, he is not included in our discussion. On the exceptional circumstances of the Armenian community in the 
1948 war and its aftermath, see Bedross Der Matossian, 'The Armenians of Palestine 1918-1948', Journal of Palestine Studies 41, 1 (2011), 24.

52 Yalkut Hapirsumim 217, 6 March 1952.

53 Iton Rishmi 50, 11 February 1949; Yalkut Hapirsumim 70, 28 February 1950.

54 One of Hawari's personal files contains documents regarding his legal efforts to regain ownership of his real estate in Jaffa (untitled, Hawari's personal files, Mada al-Carmel - Arab Center for Applied Social Research). HCJ 123/52 Hawari v. The Guardian of Absentee Property, Jaffa (not published, on file with the authors) indicates a compromise was reached, but the details were not disclosed. On the circumstances of his return, see note 66 .

55 Charles S. Kamen, 'After the catastrophe II: the Arabs in Israel, 1948-1951', Middle Eastern Studies 24, 1 (1988), 70.

56 The Haganah (Hebrew: the defence) was a Jewish paramilitary organization active during the British Mandate and the early stages of the 1948 war, until the Israel Defence Force was formed in May 1948.

57 Kamen, 'After the Catastrophe I', 465.

58 Tamir Goren, The fall of Arab Haifa in 1948 (Sede Boqer, 2006), 48 n. 3 (Heb.); Haviv Kna'an, As the British left (Tel Aviv, 1958), 135. According to Koussa's testimony in Kna'an's book, a third lawyer, Hanna Nakkarah, was also a member of the committee, but Nakkarah's name does not appear in any other source.

59 Kna'an, As the British left, 142. Goren, The fall, 84, 133-134, 207.

60 Kna'an, As the British left, 140. All translations are by the authors.

61 Koussa and Mu'ammar were not elected to the committee representing the Palestinian Arab residents in Haifa vis à vis the Israel state authorities. Minutes of the eighth meeting of the committee on Arab affairs in Haifa, 10 June 1948 and 8 July 1948, Vashitz Personal Archive in Hashomer Hatzair Archives, Israel, 95-35.26(4).

62 The Arab Liberation Army was a military unit of volunteers from various Arab states, active in the 1948 war.

63 Mustafa Abbasi, 'Nazareth in the war for Palestine: the Arab city that survived the 1948 Nakba', Holy Land and Palestine Studies 9, 2 (2010), 185-207.

64 Kamen, 'After the Catastrophe I', 465.

65 Although one of these lawyers, Ali S. Zu'bi immigrated to Jordan in 1953.

66 It seems that Hawari's return was sanctioned by the Israeli government to create a political counterbalance to the Communist Party among the Palestinian population. See Adel Manna, Nakba and survival: the story of the Palestinians who remained in Haifa and the Galilee, 1948-1956 (Jerusalem, 2017), 304 (Heb.). 67 Nakkarah, Memories, 159-228; 'Free Hanna Nakkarah and move him to a hospital immediately', al-Ittihad, 22 November 1948 (Ara.).

68 Israel HCJ 112/53 Nakkarah v. Minister of the Interior, Piskey Din 7 (1953), 955-61 (Heb.); Nakkarah, Memories of a Palestinian lawyer, 159-232. Nakkarah's petition for full Israeli citizenship was granted on a technicality. For some reason, he was allowed to be a candidate in the municipal elections in Haifa, thus creating an estoppel, preventing the state from arguing that he was not a citizen.

69 The 1949 armistice signed in Rhodes by Israel and some Arab states included an exchange of territories between Israel and Jordan. This exchange gave Israel control over an area known as 'the little triangle', formerly held by Jordan, where the village of Jaljuliya is located.

70 Israel HCJ 46/50 Ayyobi v. Minister of Defence, Piskey Din 4 (1950), 221-32 (Heb.).

71 On the obstacles put before Palestinians in securing their legal status and obtaining an Israeli ID, see Shira Robinson, Citizen strangers: Palestinians and the birth of Israel's liberal settler state (Stanford, 2013), 68-112.

72 For a comprehensive discussion of the military rule and its control mechanisms, see Sabri Jiryis, The Arabs in Israel, 2nd edn (New York, 1976); Sarah Ozacky-Lazar, 'The crystallization of mutual relations between Jews and Arabs in the State of Israel - the first decade 1948-1958', (PhD dissertation, University of Haifa, 1996) (Heb.); Robinson, Citizen strangers.

73 Letter from Lieut. Colonel Emmanuel Mor, head of the military rule, to the military governors of the Galilee, Central and Negev military zones, 10 December 1950, IDF Archive, Kiryat Ono, Israel, 1954/ 300-45.

74 On the functions and authorities of the prime minister's advisor on Arab affairs, see Yair Bäuml, $A$ blue and white shadow: the Israeli establishments' policy and actions among its Arab citizens: the formative years 1958-1968 (Haifa, 2007), 93-6 (Heb.). 
75 On the importance of an association in uniting members of a certain occupational group through the process of professionalization, see Michael Burrage, 'Introduction: the profession in sociology and history', in Burrage and Torstendahl eds., Professions in theory and history, 11.

76 The Ayyobi affair is described in detail in the ruling referenced in note 70 .

77 The affair was covered by the media and was even discussed in the Knesset: Divrey ha-Knesset, session 144, 29 May 1950, 1501 (Heb.).

78 Manna, Nakba and survival, 282.

79 Arabs who left Israel's territory during the 1948 war were declared 'absentees' after the war; their property was put under state control and managed by the 'custodian for absentee's property' and in fact, confiscated. See Absentees' Property Law, 1950-5710. Newspaper coverage of the Ayyobi case specified that he managed to reclaim his property, but failed to mention the exact legal process by which the property was reclaimed. See 'Injunction against the deportation of advocate Ayyobi', Al Hamishmar, 31 March 1950, 2 (Heb.).

80 Israel State Archives, Jerusalem (hereafter ISA), GL 17110/6; ISA, GL 17110/5.

81 Letter from Yehoshua Palmon, Arab Affairs Advisor, Prime Minister's Office, to the General Manager, Ministry of Justice, 1 March 1950, ISA, GL 17110/6, 17-9.

82 Ziv, 'Combining professionalism', 1637.

83 Oren Bracha, 'Unfortunate or perilous: the infiltrators, the law and the Supreme Court 1948-1954', Iyuney Mishpat 21, 2 (1998), 378-85 (Heb.). Ziv also points out the gap between lawyers' professional ethics and culture of formality and individualism, and the Zionist culture of informality, improvisation, flexibility and collective solidarity. Ziv, Combining professionalism', 1634-6.

84 Burrage, Jarausch, and Siegrist, 'An actor-based framework', 205, 207; Ziv, 'Combining professionalism', $1630-1$.

85 Letter from president and secretary of the Israel Bar Association to Yehoshua Palmon, 26 December 1949, ISA, GL 17110/5, 3.

86 'A Review of the Central Committee's Actions June 1949-February 1950', Hapraklit 7 (1950), 300 (Heb.).

87 Letter from Yehoshua Palmon to the Central Committee, Israel Lawyers' Association, 6 January 1950, ISA GL 17110/5, 2.

88 Letter from Yehoshua Palmon to the General Manager, Ministry of Justice and the acting Chief Registrar, 24 October 1949, ISA GL 17110/6, 10.

89 Letter from Zvi Eli Baker to Yehoshua Palmon, 6 March 1949, ISA GL 17110/6, 11. The date is incorrect, as this is a reply to Palmon's letter from October 1949.

90 Letter from Zvi Eli Baker to Yehoshua Palmon, 10 November 10 1949, ISA GL 17110/6, 12-3.

91 Letter from Haim Cohen to Yehoshua Palmon, 9 March 1950, ISA GL 17110/6, 14.

92 See note 70.

93 'Who encourages migration to Libya?!', al-Ittihad, 16 February 1952; Manna, Nakba and survival, 192-3.

94 Israel HCJ 112/53, 'Nakkarah v. Minister of the Interior', Piskey Din 7 (1953), 955-61 (Heb.).

95 From the Head of the Legal Council to Mohammad Nimer Hawari, 21 July 1952, file titled 'Majlis al-Huquq al-Quds', Hawari's Personal files kept at Mada al-Carmel - Arab Center for Applied Social Research.

96 'Wadi' Boustani is dead', Davar, 20 January 1954, 1 (Heb.).

97 'Haifa Arab lawyer invited to Jordan', Davar, 3 July 1953, 5 (Heb.).

98 Law Council Appeal 1/51, 'Advocate Ploni v. Chairman and Members of the Law Council', Piskey Din 6 (1952), 234 (Heb.). Ploni is the Hebrew equivalent of 'John Doe'.

99 The anonymous lawyer is most likely Wadi' Boustani. The offices were located at 6 Stanton St, Haifa, a building owned at the time by British author Frances Newton, who was deported from Palestine in the late 1930s owing to pro-Palestinian activities. Boustani was her 'agent and attorney' in Israel. See ISA G-1323/19. 100 On Jarjoura's term as a member of the Knesset, see Orna Cohen, 'The survivors: Arab members of Knesset in satellite lists of Zionist parties', in Aziz Haidar ed., Political aspects of the lives of Arab citizens in Israel (Jerusalem, 2018), 111-35 (Heb.).

101 HCJ 73/53, 87/53, Kol Ha'am Ltd.; al-Ittihad Ltd. vs. The Minister of the Interior, 7 Piskey Din. 871 (1953).

102 Isaac Amit, 'From the Bill of Rights to Basic Laws: constitutional rights in Israel', Cardozo Journal of International and Comparative Law 25 (2017), 485. 
103 For a review of the 1958 statute of limitations debate and its legal implications, see Sandy Kedar, 'Minority time, majority time: land, nation and the law of adverse possession in Israel', Iyuney Mishpat 21 (1998), 665-746 (Heb.).

104 Minutes of the Knesset Subcommittee of the Constitution, Law and Justice Committee, 26 November 1957.

\section{French Abstract}

Avocats en transition. Les avocats arabes palestiniens dans la première décennie de l'État d'Israël

Cet article retrace les carrières de douze avocats arabes palestiniens qui ont exercé leur métier au cours des dernières années du Mandat britannique sur la Palestine (1920-1948) et sont devenus citoyens de l'Etat d'Israël après 1948. Ce dernier s'est efforcé de surveiller ces avocats palestiniens et de limiter leur pratique. Pourtant, malgré les pressions subies, la plupart d'entre eux ont poursuivi leur profession et sont devenus actifs dans la sphère publique israélienne. Nous montrons comment la lutte de ces Palestiniens pour maintenir leur activité en Israël a été utilisée pour affirmer l'autonomie des juristes de ce volet professionnel, tout en étant vécue comme pierre de touche pour les droits civils des minorités en Etat d'Israël.

\section{German Abstract}

Anwälte in einer Übergangsphase - Palästinensisch-arabische Anwälte im ersten Jahrzehnt des jüdischen Staates.

Dieser Beitrag verfolgt die Karrieren von zwölf palästinensisch-arabischen Anwälten, die in den letzten Jahren des britischen Mandats in Palästina (1920-1948) praktizierten und nach 1948 israelische Staatsbürger wurden. Der Staat Israel war bestrebt, palästinensische Anwälte in ihrer Berufsausübung $\mathrm{zu}$ beschränken und sie $\mathrm{zu}$ überwachen, doch trotz dieses Drucks praktizierten die meisten von ihnen weiter und wurden auch in der israelischen Öffentlichkeit aktiv. Wir zeigen, dass der Kampf der palästinensischen Anwälte um die Aufrechterhaltung ihres Berufs dazu beitrug, die Autonomie der Anwaltschaft zu behaupten, und gleichzeitig als Prüfstein angesehen wurde, um die Bürgerrechte einer Minderheit innerhalb des Staates zu sichern. 